\title{
In vitro antimicrobial and antihelminthic activity of the ethanolic extracts of Allium sativum, Allium cepa, Lantana camara, Averrhoa carambola and Syzygium aromaticum
}

\author{
Dibua, Uju M. E. ${ }^{1 *}$ and Odo, G. E. ${ }^{2}$ \\ ${ }^{1}$ Department of Microbiology, University of Nigeria, Nsukka, Nigeria. \\ ${ }^{2}$ Department of Zoology, University of Nigeria, Nsukka, Nigeria.
}

Accepted 4 May, 2012

\begin{abstract}
The antimicrobial and antihelminthic activities of the ethanolic extracts of Allium sativum, Allium cepa, Lantana camara, Averrhoa carambola and Syzygium aromaticum were investigated. The ethanolic extracts were screened against three urinary tract pathogens Pseudomonas aeruginosa (ATCC 10145) and Escherichia coli (ATCC 11775); Candida albicans and two gastrointestinal isolates (clinical samples); Salmonella typhi and Proteus mirabilis, using the agar diffusion technique at 100, 50, 25, 12.5 and $62.5 \mathrm{mg} / \mathrm{ml}$ concentrations. The bioassay was carried out on 70 local earthworms (Pheretima posthuma): 10 live worms in $20 \mathrm{mg} / \mathrm{ml}$ of each ethanolic extract; $20 \mathrm{mg} / \mathrm{ml}$ of piperazine and $20 \mathrm{mg} / \mathrm{ml} \mathrm{of}$ $5 \%$ dimethylformamide (DMF). A. sativum and $A$. cepa showed high activity on all isolates $(P<0.05)$, with inhibition zone diameter (IZD) at $50 \mathrm{mg} / \mathrm{ml}$ concentration ranging from $19.5 \pm 0.00$ to $23.0 \pm 0.00$ $\mathrm{mm}$; and $16.5 \pm 0.25$ to $22.5 \pm 0.20$ for $A$. sativum and $A$. cepa; minimal inhibitory concentration (MIC), 0.48 to $1.0 \mathrm{mg} / \mathrm{ml}$ for both bacterial and fungal pathogens. Antihelminthic activity of the extracts $(P<$ 0.05 ) was in the order: $A$. sativum $>A$. cepa $S$. aromaticum $>L$. camara $>A$. carambola. The study established their use in the management of gastrointestinal and urinary tract infections which is consistent with their use in folk-medicine
\end{abstract}

Key words: Antimicrobial, antihelminthic, minimal inhibitory concentration, ethnomedicine, gastrointestinal and urinary tract infections.

\section{INTRODUCTION}

Traditional medicine still plays an important role in primary health care in Nigeria as many infectious diseases are known to be treated with herbal remedies (Apata, 1992). The use of plant extracts and phytochemicals, both with known antimicrobial properties, have been identified by the World Health Organization as alternative sources of therapeutic treatments (World Health Organization - WHO, 2001). Medicinal plants therefore remain significant as therapeutic remedies in

\footnotetext{
${ }^{\star}$ Corresponding author. E-mail: oby2112@yahoo.co.uk. Tel:
} +2348037792951. many developing countries (Lino and Deogracious, 2006; Idu and Onyibe, 2007). The beneficial medicinal effects of plant materials typically result from the combinations of their secondary metabolites; and their medicinal actions are unique to particular plant species or groups and this is based on their distinct taxonomy (Wink, 1999). Plantderived drugs thus serve as a prototype to develop more effective and less toxic medicines.

Lantana camara belonging to the family Verbenaceae has many ethnomedicinal uses in the treatment of tetanus, high fever, cough, influenza, malaria, mumps, eczema measles/chicken pox, constipation, catarrh, bronchitis and tuberculosis (Sharma and Sharma, 1989; Raghu et al., 2004; Basu and Hazra, 2006). Allium 
sativum, commonly known as garlic, has been found to be of very high therapeutic importance. The extract of garlic was found to have a significant protective action against a fat induced increase in serum cholesterol and plasma fibrinogen and in fibrinolytic activity (Gadkari and Joshi, 1991; Yu and Qureshi, 1991; Yeh, 2001). The antifungal properties of allicin and ajoene isolated from garlic (A. sativum) were demonstrated (Moore and Atldo, 1977; Yoshida et al., 1987; Davis et al., 1990). The fruits of Averrhoa carambola (Oxalidaceae) have been also implicated in the treatment of hypertension, diabetes, arthritis as well as diarrhea (Morton, 1987; Jabbar et al., 1995).

Resistance of Candida albicans to broad spectrum drugs as well as the resultant side effects of these drugs ranging from nephrotoxicity or hepatotoxicity (Dupont et al., 2006) has necessitated the search for alternative but effective plant oils such as those present in Syzygium aromaticum (clove) for such therapeutic uses. The most important and the major compound constituent in clove is the volatile oil eugenol - chemically identified as a phenol, which has very strong antiseptic and anesthetic properties as pain relief agent for toothache and other dental problems.

The increasing number of multi-drug resistant microbial strains and the appearance of strains with reduced susceptibility to antibiotics have been attributed to indiscriminate use of broad-spectrum antibiotics, immunosuppressive agents, intravenous catheters, organ transplantation and ongoing epidemics of HIV infection (Dean and Burchard, 1996; Gonzalez et al., 1996). In addition, synthetic drugs are not only expensive and inadequate for the treatment of diseases in developing countries, but are also often with adulterations and side effects. The growing world-wide concern about the alarming increase in the rate of infection by antibioticresistant microorganisms (Davies, 1994; Sieradzki et al., 1999) have therefore necessitated this search for alternative therapeutic remedies found in plant extracts. About $80 \%$ of individuals from resource poor countries use traditional medicines, which have compounds derived from medicinal plants, hence the need for further evaluation of the constituents of these plants for health purposes.

The escalating incidence of typhoid, paratyphoid fever and urinary tract infections among the local populace in Nigeria has necessitated the search for effective alternative therapeutants derived from plants, including those commonly used as salad dressing, in culinary or spices.

The present study is aimed at carrying out the preliminary phytochemical analysis as well as the in vitro screening for the antimicrobial and antihelminthic activity of some medicinal plants used in Nigeria and those used as spices or salad dressings, against some drug resistant urinary tract infection (UTI) and enteric fever pathogens.

\section{MATERIALS AND METHODS}

\section{Microorganisms}

The test bacteria comprised two typed culture isolates: Pseudomonas aeruginosa (ATCC 10145) and Escherichia coli (ATCC 11775), obtained from the BDCP Laboratories Nsukka, and two clinical isolates; Salmonella typhi and Proteus mirabilis, from Clinical Diagnostic laboratory of the Department of Microbiology, University of Nigeria, Nsukka. Clinical isolate of Candida albicans from high vaginal swabs (HVS) samples of antenatal mothers in recognized hospitals at Nsukka metropolis were used as the only test fungus. An inoculum of each microorganism was reconstituted in $3 \mathrm{ml}$ of nutrient broth. The bacterial species were cultured in the Mueller-Hinton broth, while the yeast species was cultured in Sabouraud dextrose (SDB) broth (Oxoid). All cultures were incubated on a shaker at $37^{\circ} \mathrm{C}$ for $18 \mathrm{~h}$ and then diluted to $1 / 10$ the concentration to yield a culture density of approximately $3 \times 10^{8}$ $\mathrm{CFU} / \mathrm{ml}$ (0.5 McFarland).

\section{Plant collection}

The leaves of $A$. carambola and $L$. camara used were collected from the premises of the University of Nigeria Nsukka, between July and August, 2010. Taxonomic identification was confirmed by experts at the Herbarium of the Department of Botany, while cloves, the rich, brown, dried, unopened flower buds of $S$. aromaticum was purchased from Chinese Supermarket at the urban city of Enugu, Nigeria. A. sativum and Allium cepa were procured from the fruits shops at Ogige Market, Nsukka, in August, 2010.

\section{Preparation of crude extract}

A. carambola and L. camara leaves were thoroughly washed, shade-dried for 7 days and ground in an electric blender, Moulinex Master chef Delicio (Type DFB1). One gram of each powdered plant was extracted with $10 \mathrm{ml}$ absolute ethanol. Each crude extract was filtered through Whatman No. 3 filter paper and the filtrate concentrated in vacuo using a rotor evaporator for solvent evaporation. Dried extract was reconstituted in $10 \mathrm{ml}$ dimethylsulphoxide (DMSO) prior to use.

The bulbs of $A$. sativum and $A$. cepa extracts were prepared according to the method described by Bakri and Douglas (2005). Eighty grams $(80 \mathrm{~g})$ of the peeled fresh garlic was chopped and homogenized using the Moulinex Masterchef Delicio (Type DFB1). The homogenate was suspended in absolute ethanol for extraction, and then centrifuged, filtered through Whatman No.1 filter paper and further re-centrifuged through Whatman No.3. This was then rotor-evaporated to remove the ethanol before suspending in DMSO. The final concentration of garlic extract in DMSO was determined by subtracting the weight of insoluble material from the weight of original sample to give $64 \%(\mathrm{w} / \mathrm{v})$ of extract. The filtrate was then kept at about $-70^{\circ} \mathrm{C}$ until used. The concentration of allicin was however not determined.

\section{Phytochemical analysis}

Qualitative phytochemical analysis of plant extracts was carried out according to the method described by Trease and Evans (1978) and Harborne (1973) as follows:

\section{Flavonoids}

Lead acetate test: Briefly, $2.0 \mathrm{ml}$ of each ethanolic extract was 
added $10 \%$ lead acetate solution and observed for a coloured precipitate indicative of flavonoids.

\section{Tannin}

To $2.0 \mathrm{ml}$ of distilled water was added $0.1 \mathrm{~g}$ of each extract, boiled for $2 \mathrm{~min}$, filtered and allowed to cool. To this was then dispensed $5 \%$ ferric chloride $\left(\mathrm{FeCl}_{3}\right)$ solution drop-wise and observed for colour change.

\section{Saponins}

The presence of saponins was assayed by the frothing test. Approximately $5 \mathrm{mg}$ of extract was added into $5 \mathrm{ml}$ of distilled water, shaken vigorously and observed for persistent frothing.

\section{Alkaloid}

Approximately $2.0 \mathrm{ml}$ of each ethanolic extract was added to $5 \mathrm{ml}$ of $2 \%$ hydrochloric acid and allowed to steam in a water bath for 20 $\mathrm{min}$, and then filtered. To $1 \mathrm{ml}$ of each filtrate was dispensed 2 drops of Dragendroff's reagent (bismuth potassium iodide solution) and observed for precipitation.

\section{Steroids and terpenoids}

The Salkowski's test was used in testing for steroids. Approximately $5 \mathrm{ml}$ of each ethanolic extract was evaporated to dryness and the residue re-dissolved in $5.0 \mathrm{ml}$ of anhydrous chloroform and then filtered. To each filtrate in a $10 \mathrm{ml}$ test tube was carefully dispensed $2.0 \mathrm{ml}$ of concentrated sulphuric acid until a bi-layer was formed. The interface was then observed for a reddish brown coloration indicative of steroid. About $2 \mathrm{ml}$ of each extract was further dried by evaporation, and to this was dispensed $2 \mathrm{ml}$ of anhydrous chloroform and filtered. To a $2 \mathrm{ml}$ filtrate was simultaneously added $2 \mathrm{ml}$ acetic anhydride and $2 \mathrm{ml}$ concentrated $\mathrm{H}_{2} \mathrm{SO}_{4}$ and carefully observed for the appearance of a blue-green ring indicating the presence of terpenoids.

\section{Cardiac glycosides}

The Keller-Kiliani test was adopted: To a $2 \mathrm{ml}$ filtrate was dispensed $1 \mathrm{ml}$ glacial acetic acid, $\mathrm{FeCl}_{3}$ and concentrated $\mathrm{H}_{2} \mathrm{SO}_{4}$, and observed for green-blue coloration indicative of cardiac glycosides.

\section{Evaluation of antimicrobial activity using the agar diffusion technique}

A preliminary antibiogram was carried out to ascertain the activity of the test extracts by spot-checking at a concentration of $250 \mathrm{mg} / \mathrm{ml}$ using agar well diffusion technique. Subsequently, the antibacterial and antifungal activities of the ethanolic extracts were determined by the agar well diffusion method (Nair et al., 2005). A $500 \mathrm{mg}$ amount of each ethanolic extract was dissolved in dimethylsulphoxide (DMSO) and then serially diluted to final concentrations of $100,50,25,12.5$ and $62.5 \mathrm{mg} / \mathrm{ml}$. The freshly prepared Mueller Hinton agar No.2 (Hi Media) and Sabouraud dextrose agar (SDA) plates were seeded with suspensions of the $18 \mathrm{~h}$ old bacterial and fungal isolates identical in turbidity with McFarland 0.5 standard $\left(3 \times 10^{8} \mathrm{CFU} / \mathrm{ml}\right)$ and allowed to dry. Wells,
$8 \mathrm{~mm}$ in diameter, were bored on the agar plates with a sterile corkborer and to each well were dispensed $0.2 \mathrm{ml}$ of each extract and allowed to stand for $2 \mathrm{~h}$ at room temperature for complete diffusion into the agar. Excess suspensions were drained and the plates were then incubated at $37^{\circ} \mathrm{C}$ for $24 \mathrm{~h}$.

Microbial growth was determined by measuring the inhibition zone diameter (IZD) to nearest $\mathrm{mm}$ for concentrations of extracts that showed activity. The minimum inhibitory concentration (MIC) was taken as the antilog of the intercept on the log concentration axis of a graph of log concentration versus IZD', according to the method of Esimone and Adikwu (1999). Pure (uninoculated) DMSO was taken as the negative control while $100 \mu \mathrm{g} / \mathrm{ml}$ each of $500 \mathrm{mg}$ of gentamicin and nystatin, (Sigma Chemical Co) were used as positive controls for antibacterial and antifungal activity. Fungal suspension was incubated for 3 to 5 days; dishes were examined for zones of growth inhibition and the diameters of these zones measured in millimeter using the Interpretative chart of Fidson Healthcare LTD (Mumbai India), and subsequently interpreted as susceptible or resistant according to the zone sizes.

\section{Bioassay and antihelminthic activity of test plant}

The antihelminthic bioassay was carried out using 70 live local earthworms (Pheretima posthuma) identified at the Zoological museum of Zoology Department, University of Nigeria. These were carefully collected with disposal gloves from moist soil of the Sewage Disposal Areas near the Junior Staff Quarters of the University of Nigeria, Nsukka, and thoroughly cleared of soil and debris with clean water before rinsing in normal saline to ensure removal of faecal matter and adhering debris before the commencement of the bioassay. Ten (10) of the earthworms $(P$. posthuma) of similar sizes were gently dropped into $20 \mathrm{mg} / \mathrm{ml}$ of each ethanolic extract; $20 \mathrm{mg} / \mathrm{ml}$ of piperazine; and $20 \mathrm{mg} / \mathrm{ml}$ of the control ( $5 \% \mathrm{DMF})$, respectively, in $50 \mathrm{ml}$ conical flask. These were then observed for $24 \mathrm{~h}$ for significant behavioral responses (morbidity behaviors) ranging from erratic movement, contraction and relaxation of circular and longitudinal muscles, slower or irregular movement and pale appearance as well as time of killing as described by Dibua and Okpokwasili, (2006).

\section{RESULTS}

\section{Phytochemistry of ethanolic extracts}

The result of the phytochemistry of test plant extracts aimed at determining the chemical constituents in the plants that could have potential for therapeutic uses are elucidated in Table 1. S. aromaticum and A. carambola have high amounts of reducing sugars $(+++)$, while $A$. cepa and $L$. camara was rich in tannin $(+++)$. Glycoside was high in $A$. cepa $(+++)$ and low in $A$. sativum (+). Similarly, terpenoids was high in $S$. aromaticum (+++) and moderate $(++)$ in $A$. cepa and $A$. carambola. Furthermore, alkaloid was low in A. cepa and L. camara and absent in others.

Table 2 outlines the susceptibility of isolates to the ethanolic extracts established at $50 \mathrm{mg} / \mathrm{ml}$. Ethanolic extract of $A$. sativum had remarkable activity on all test isolates, with IZD of $23.0 \pm 0.00 \mathrm{~mm}$ for $E$. coli, $27.0 \pm$ $0.00 \mathrm{~mm}$ for $P$. mirabilis, $21.0 \pm 0.20 \mathrm{~mm}$ for $S$. typhi, 19.5 
Table 1. Phytochemical constituents test plant extracts.

\begin{tabular}{lccccc}
\hline Compound & Allium sativum & Allium cepa & L. camara & S. aromaticum & A. carambola \\
\hline Carbohydrate & + & ++ & + & + & ++ \\
Reducing sugar & + & + & +++ & +++ & - \\
Tannin & + & +++ & - & - & ++ \\
Cardiac Glycosides & + & ++ & - & + & - \\
Saponins & + & ++ & + & + & + \\
Terpenes & - & + & + & - \\
Flavonoids & + & + & + & - \\
Alkaloids & - & & & + \\
\hline
\end{tabular}

+, Low; ++, moderate; +++, high; -, absent.

Table 2. Sensitivity of extracts against test bacterial and fungal isolates.

\begin{tabular}{|c|c|c|c|c|c|c|}
\hline \multirow{2}{*}{ Test Plant } & \multirow{2}{*}{ Concentration } & \multicolumn{5}{|c|}{ IZD (mm) } \\
\hline & & E.coli & P. mirabilis & S. typhi & P. aeruginosa & C. albicans \\
\hline Control: Ethanol & - & 0 & 0 & 0 & 0 & 0 \\
\hline Nystatin & $100 \mu \mathrm{g} / \mathrm{ml}$ & 0 & 0 & 0 & 0 & $12.5 \pm 0.20$ \\
\hline Allium sativum (garlic) & $50 \mathrm{mg} / \mathrm{ml}$ & $23.0 \pm 0.00$ & $27.0 \pm 0.00$ & $21.0 \pm 0.20$ & $19.5 \pm 0.00$ & $21.5 \pm 0.25$ \\
\hline A. Сера & $50 \mathrm{mg} / \mathrm{ml}$ & $19.0 \pm 0.00$ & $22.5 \pm 0.20$ & $19.5 \pm 0.00$ & $16.5 \pm 0.25$ & $17 \pm 0.00$ \\
\hline A. carambola & $50 \mathrm{mg} / \mathrm{ml}$ & $11.5 \pm 0.25$ & $14.5 \pm 0.00$ & $10.0 \pm 0.25$ & $9.0 \pm 0.00$ & $11.5 \pm 0.25$ \\
\hline S. aromaticum & $50 \mathrm{mg} / \mathrm{ml}$ & $18.0 \pm 0.25$ & $15.0 \pm 0.00$ & $21.0 \pm 0.20$ & $19.0 \pm 0.25$ & $13.0 \pm 0.25$ \\
\hline
\end{tabular}

$\pm 0.00 \mathrm{~mm}$ for $P$. aeruginosa and $21.5 \pm 0.25 \mathrm{~mm}$ for $C$. albicans. Similarly, sensitivity of isolates to $A$. cepa was established by their IZD at $50 \mathrm{mg} / \mathrm{ml}: 19.0 \pm 0.00 \mathrm{~mm}$ for E. coli, $22.5 \pm 0.20 \mathrm{~mm}$ for $P$. mirabilis, $19.5 \pm 0.00 \mathrm{~mm}$ for S. typhi, $16.5 \pm 0.25 \mathrm{~mm}$ for $P$. aeruginosa and $17.0 \pm$ $0.00 \mathrm{~mm}$ for $C$. albicans. Moderate activity was nonetheless observed with $L$. camara on test organisms at $50 \mathrm{mg} / \mathrm{ml}$ : IZD of isolates; $13.5 \pm 0.00 \mathrm{~mm}$ for $P$. mirabilis, and $12.0 \pm 0.00 \mathrm{~mm}$ for $P$. aeruginosa. Sensitivity of isolates to $A$. carambola on the other hand was similarly moderate at the used concentration: IZD of $P$. mirabilis was $14.5 \pm 0.00 \mathrm{~mm}$. Furthermore, sensitivity of isolates to $S$. aromaticum was appreciable at 50 $\mathrm{mg} / \mathrm{ml}$ : IZD ranged from $21.0 \pm 0.20 \mathrm{~mm}$ for $S$. typhi, to $13.0 \pm 0.25 \mathrm{~mm}$ for $C$. albicans.

The activity of the ethanolic extracts on isolates was further exhibited by their dose-effect response (Figures 1 to 5). The control antibiotic, gentamicin, had moderate activity on isolates at $100 \mu \mathrm{g} / \mathrm{ml}$ : IZD ranged from $11.0 \pm$ 0.70 for $P$. aeruginosa to $8.0 \pm 0.00$ for $S$. typhi, while the antifungal agent, nystatin was moderately active only on C. albicans at $100 \mu \mathrm{g} / \mathrm{ml}$, with IZD of $12.5 \pm 0.20$. The estimated marginal mean sensitivity of both the ethanolic extracts and the controls on the test isolates (Figure 6), indicated that $S$. sativum has the overall best estimated mean sensitivity on the test micro organisms with its graph lying highest along the x-axis. On the susceptibility, the MIC of Allium sativum against test isolates by the agar diffusion method, ranged from $0.974 \mathrm{mg} / \mathrm{ml}$ for $E$. coli and $P$. mirabilis to $0.852 \mathrm{mg} / \mathrm{ml}$ for $S$. typhi. Moreover, A. cepa had MIC ranging from $0.991 \mathrm{mg} / \mathrm{ml}$ for $P$. aeruginosa to $0.908 \mathrm{mg} / \mathrm{ml}$ for $E$. coli and $P$. mirabilis. L. camara had MIC ranging from $1.000 \mathrm{mg} / \mathrm{ml}$ for $P$. mirabilis to $0.643 \mathrm{mg} / \mathrm{ml}$ for $S$. typhi, while that of $A$. camara was $0.970 \mathrm{mg} / \mathrm{ml}$ for $C$. albicans, $0.895 \mathrm{mg} / \mathrm{ml}$ for both $E$. coli and $P$. mirabilis, $0.868 \mathrm{mg} / \mathrm{ml}$ for S. typhi and $0.832 \mathrm{mg} / \mathrm{ml}$ for $P$. aeruginosa. MIC of $S$. aromaticum against isolates on the other hand ranged from $1.0 \mathrm{mg} / \mathrm{ml}$ for $C$. albicans to $0.479 \mathrm{mg} / \mathrm{ml}$ for $S$. typhi, respectively (Table 3).

\section{Bioassay and antihelminthic activity of test plant}

The evaluation of the in vitro antihelminthic activity of test plants compared with standard antihelminthic chemical chemotherapeutants, piperazine (results are expressed as mean $\pm S D$ from seven observations), indicated that all plant extracts used exhibited significant antihelminthic activities on the earthworm ( $P m$ posthuma) $(\mathrm{P}<0.05)$. 


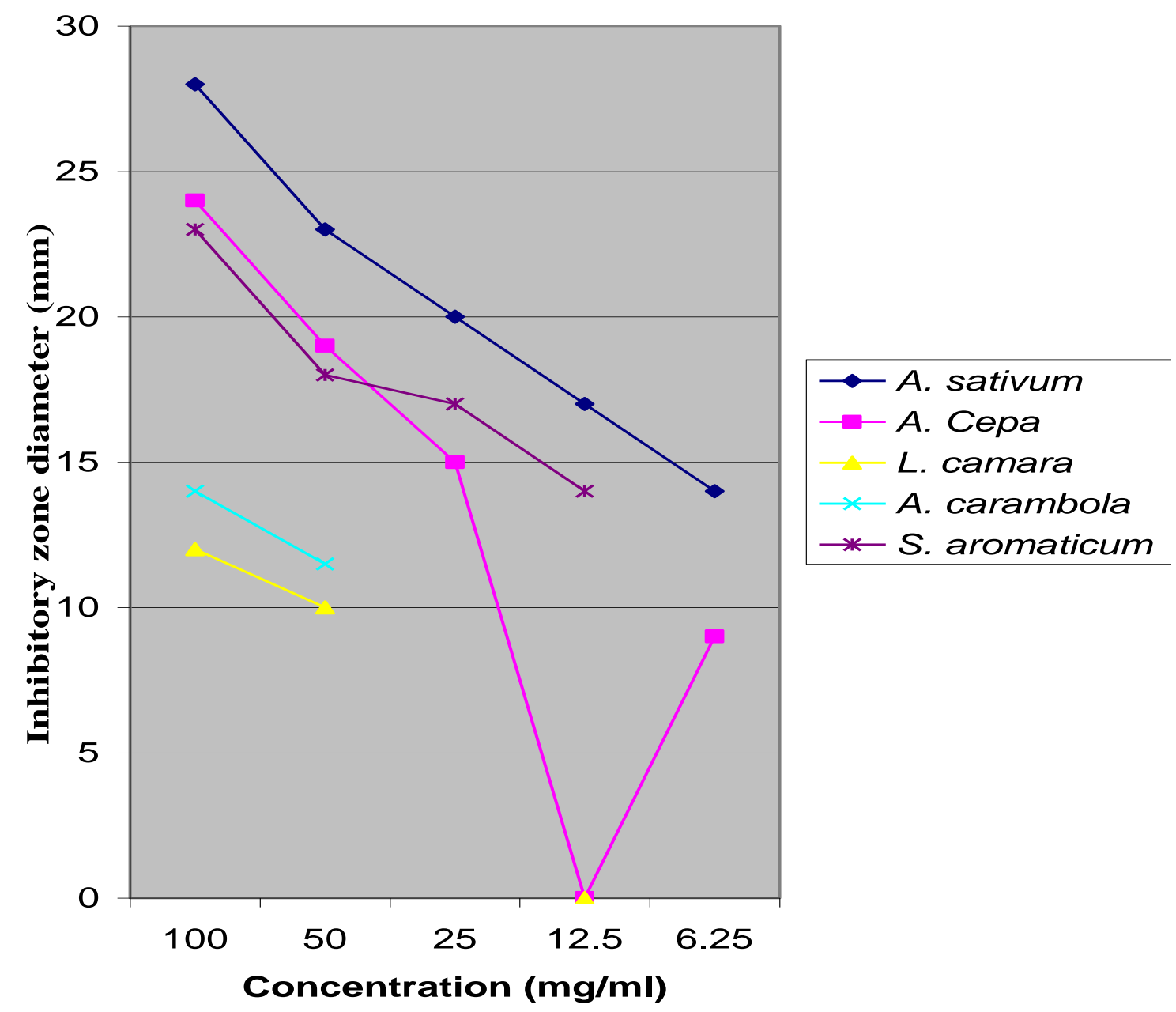

Figure 1. Dose-response effect of the ethanolic extracts of Test Plants against E. coli.
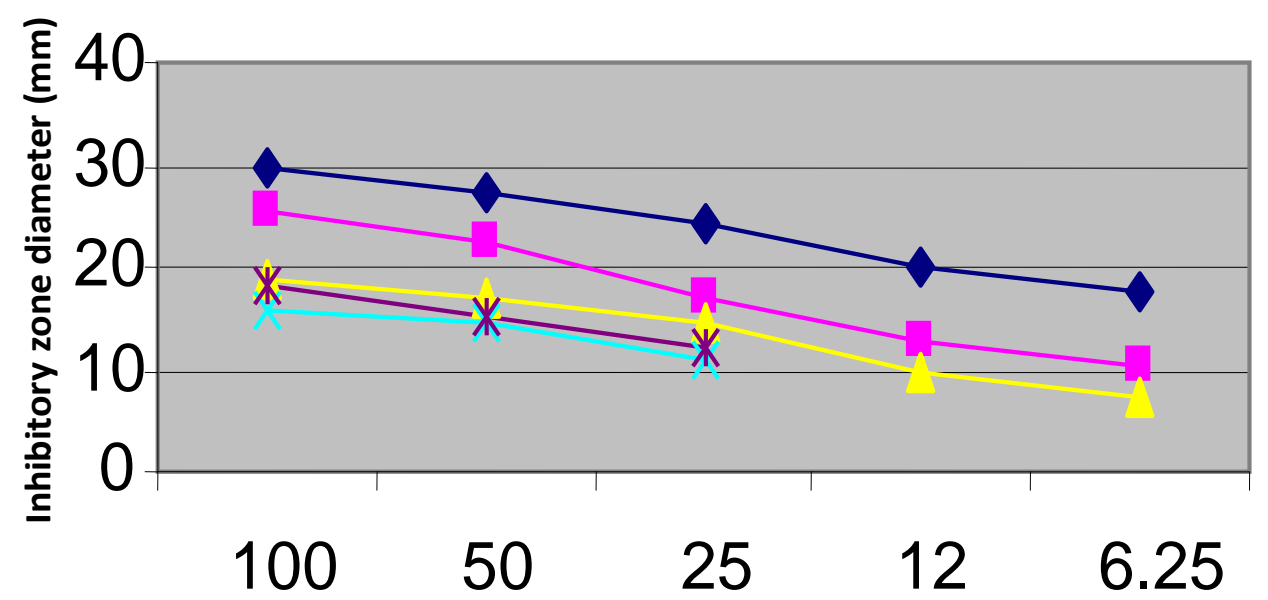

$\checkmark$ A. sativum

- A. Cepa

L. camara

A. carambola

* S. aromaticum

\section{Concentration $(\mathrm{mg} / \mathrm{ml})$}

Figure 2. Dose-response effect of the ethanolic extracts of test plants against $P$. mirabilis. 


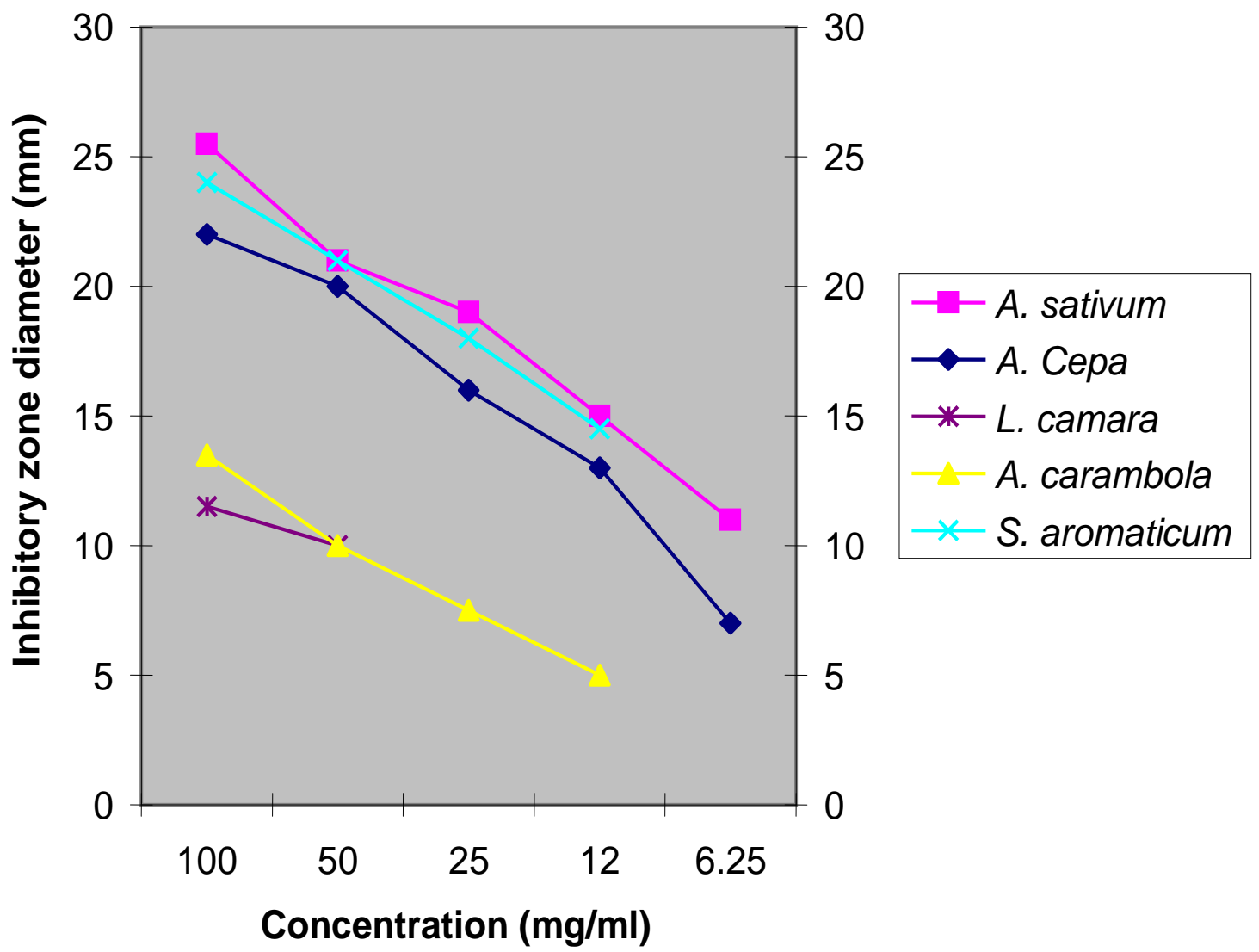

Figure 3. Dose-response effect of the ethanolic extracts of test plants against $S$. typhi.

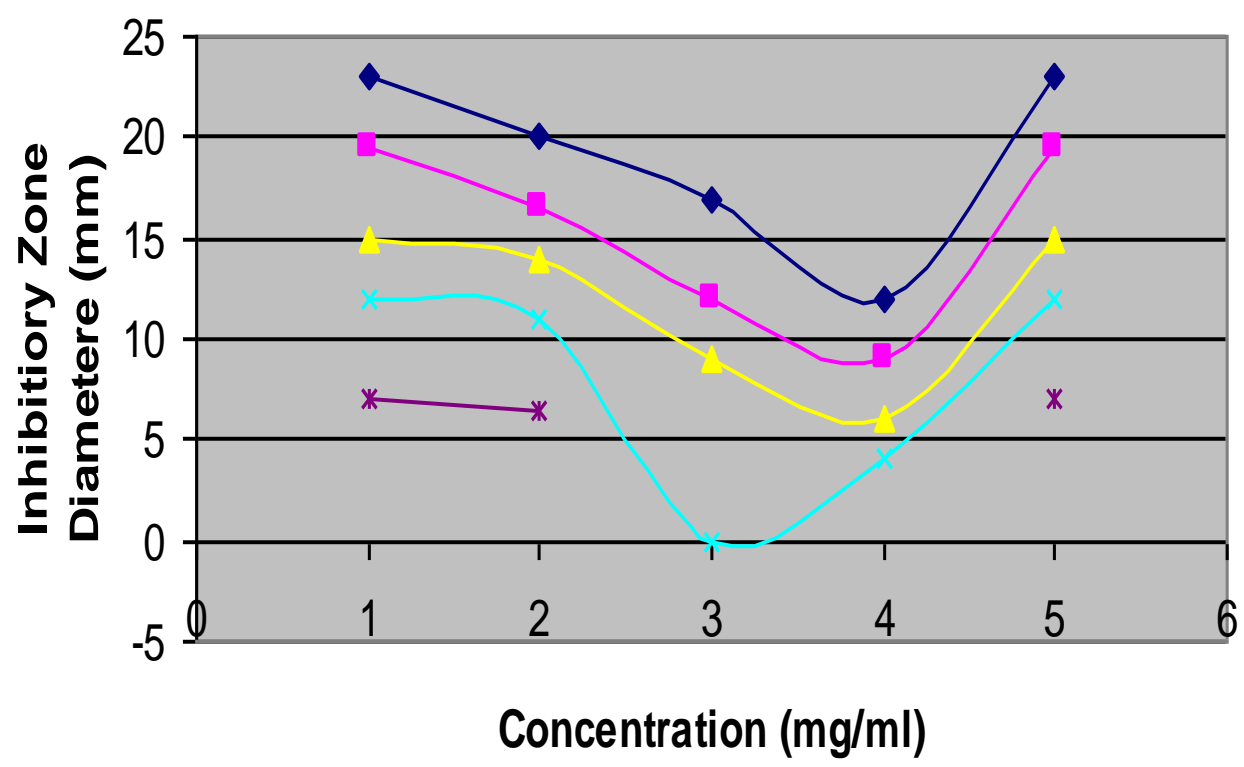

$$
\rightarrow 100 \rightarrow 50 \div 25 \div 12.5 \rightarrow 6.25
$$

Figure 4. Dose-response effect of the ethanolic extracts of test plants against $P$. aeruginosa. 


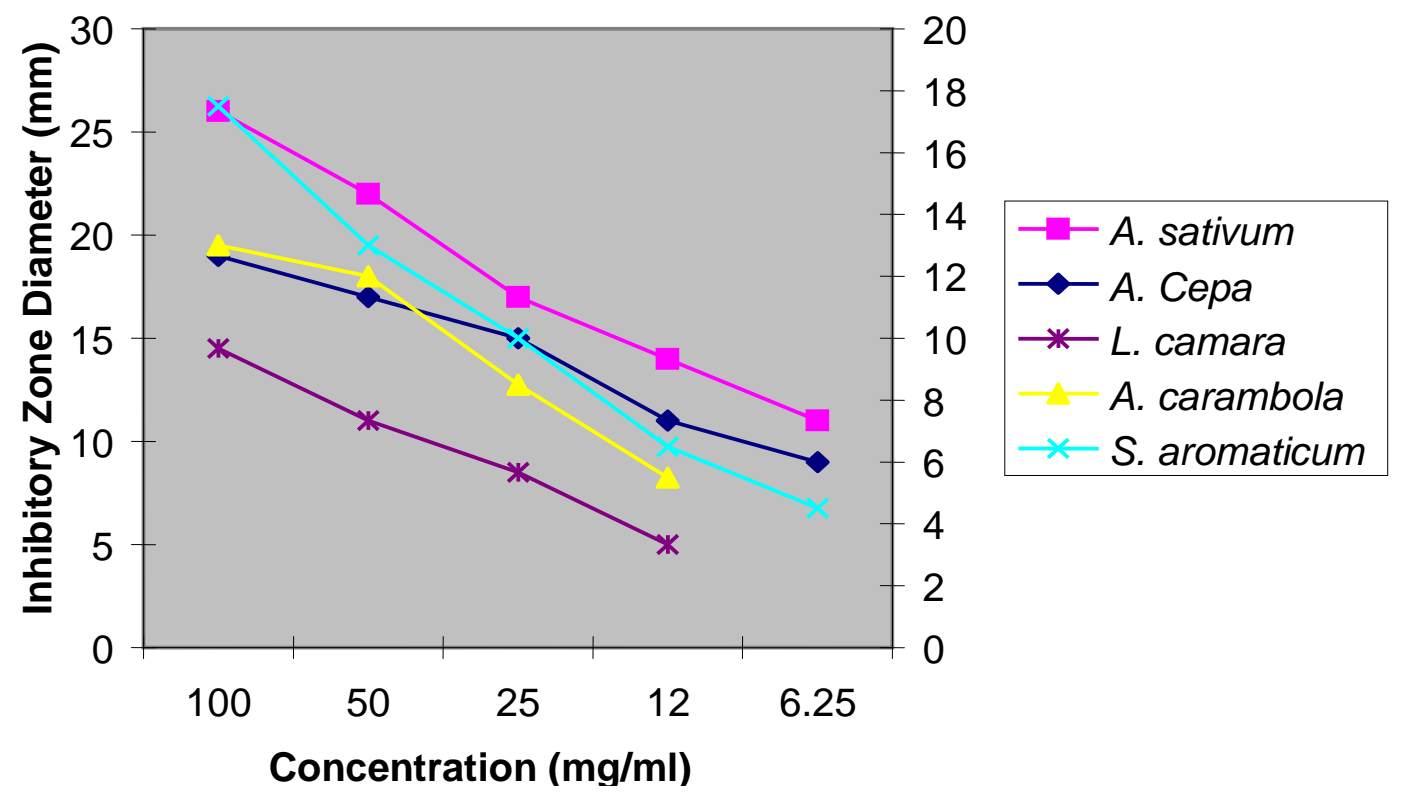

Figure 5. Dose-response effect of the ethanolic extracts of test plants against $C$. albicans.

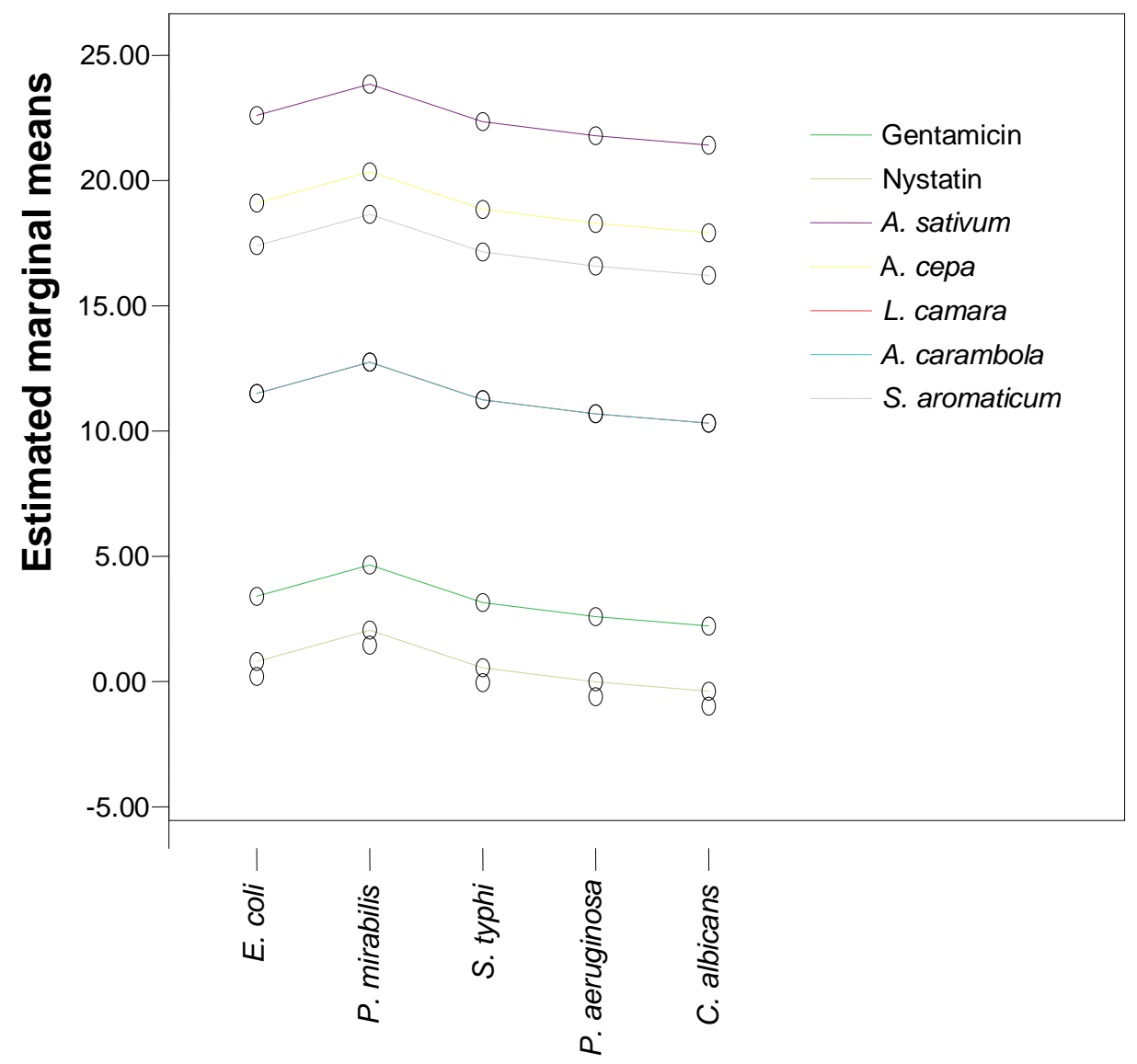

Test isolates

Figure 6. Estimated marginal means of sensitivity of ethanolic extracts. 
Table 3. The minimal inhibitory concentration (MIC) of plant extracts against test microorganisms (MIC of extracts ( $\mathrm{mg} / \mathrm{ml})$ ).

\begin{tabular}{lccccc}
\hline Isolates & Allium sativum & Allium cepa & L. camara & A. carambola & S. aromaticum \\
\hline E. coli & 0.974 & 0.908 & 0.902 & 0.895 & 0.855 \\
P. mirabilis & 0.974 & 0.908 & 1.0 & 0.895 & 0.855 \\
S. typhi & 0.858 & 0.986 & 0.643 & 0.868 & 0.479 \\
P. aeruginosa & 0.877 & 0.991 & 0.814 & 0.832 & 0.989 \\
Candida albicans & 0.921 & 0.974 & 0.899 & 0.970 & 1.0 \\
\hline
\end{tabular}

Table 4. In vitro antihelminthic activity of ethanolic extracts of test plant.

\begin{tabular}{lcc}
\hline Treatment $\mathbf{( 2 0} \mathbf{~} \mathbf{g} / \mathbf{m l})$ & Morbid behavior $(\mathbf{m i n})$ & Death $(\mathbf{m i n})$ \\
\hline A. sativum & $1.31 \pm 0.12$ & $1.52 \pm 0.20$ \\
A. cepa & $1.58 \pm 1.30$ & $1.96 \pm 0.30$ \\
S. aromaticum & $2.01 \pm 0.22$ & $2.43 \pm 0.30$ \\
L camara & $3.24 \pm 0.09$ & $4.79 \pm 0.15$ \\
A. carambola & $5.02 \pm 0.30$ & $6.10 \pm 0.21$ \\
Piperazine & $3.25 \pm 0.21$ & $4.99 \pm 0.18$ \\
Control: $5 \%$ DMF & - & - \\
\hline
\end{tabular}

The order of susceptibility was as follows: $A$. sativum $>A$. cepa $S$. aromaticum $>L$. camara $>A$. carambola (Table 4). Control worms survived for almost $24 \mathrm{~h}$ of observation. Both morbid behaviors and death were achieved at shorter time intervals by $A$. sativum $(1.31 \pm 0.120 ; 1.52$ $\pm 0.200)$ and $A$ cepa $(1.58 \pm 1.303 ; 1.96 \pm 0.298)$, respectively. However, the control antibiotic (piperazine) showed moderate activity against the organism, while no activity was exhibited by the control; normal saline.

\section{DISCUSSION}

The majority of investigations carried out in the search of compounds with antimicrobial properties in Nigeria have targeted plants of localized distribution (Nigerian origin) with ethnomedical uses (Apata, 1979; Bagchi et al., 1999; Alves et al., 2000; Edeoga et al., 2005; lbe and Martin, 2005; Idu and Onyibe, 2007), while only a few have explored those mostly native to the plains of Western Asia which the daily increasing search for improved health standards in Nigeria have emanated to their importation and subsequent consumption as in culinary, spices or in salad dressings. The present study has investigated the in vitro antimicrobial and antihelminthic activities of five plant species and their potential for therapeutic uses within the local environment against the daily increasing typhoid and paratyphoid and other enteric fevers, urinary tract infections as well as infestations by helminthes.

The phytochemical analysis of the ethanolic plant extracts indicated the presence of rich chemical compounds whose significant uses as therapeutic agents have been previously established: flavonoids, tannins, cardiac glycosides, saponins and alkaloids present in these plants have been associated with their antimicrobial activity (Mahajan and Badgujar, 2008). The broad spectrum of antibacterial and antifungal properties of $A$. sativum and $A$. cepa, notably their flavonoids, against pathogenic agents of bronchitis, pneumonia, ear infections, diarrhea, Staphylococcus and Streptococcus species, was established by Pérez-Giraldo et al. (2003). The activity of $A$. sativum against Helicobacter pylori, the cause of gastric ulcers, is due chiefly to its flavonoid, tannins and saponins constituents, making $A$. sativum (garlic) a prime candidate for therapeutic use (Ankri and Mirelman, 1999; Sivam et al., 1997). The result of this study is in conformity with the susceptibility profile of garlic extract on multi-drug resistant Gram negative organisms: E. coli, Klebsiella aerogenes and Salmonella species (Muhsin and Amina, 2007), as well as the antifungal activities of the plant in human urine and serum after ingestion of garlic $(A$. sativum) (Caporaso et al., 1983). Similarly, Grieve (1995) indicated its use in the treatment of typhus and dysentery, demonstrating its feasible clinical applications. These established activities of $A$. sativum are due chiefly to the presence of very active volatile oil, which contains allicin (diallyl thiosulphinate), in addition to the presence of other chemically active agents such as cardiac glycosides, which possess pharmacodynamic properties. The very high activity profile of $A$. sativum and $A$. cepa on all test organisms exhibited in this study authenticates earlier reports by Muhsin and Amina (2007) on the effective 
antimicrobial activity of crude juices of these plants.

The antifungal activity of $A$. carambola observed in the study has been attributed to its active ingredients, notably saponins, tannins and flavonoids, as previously reported by Morton (1987); while the good activity of L. camara on test isolates is supported by the findings of Smith (1998), on the activity of the plant against several bacterial, fungal and protozoan pathogens including those implicated in influenza, cough, mumps, incessant high fever, malaria, tuberculosis due to its saponin, terpenoids and flavonoid contents (Begum et al., 2003). The mycotic activities of $S$. aromaticum were similarly apparent in the study: C. albicans was inhibited at MIC $50 \mathrm{mg} / \mathrm{ml}$, with IZD of $13.0 \pm 0.25$, signifying moderate activity of the extract on the fungi. This view is supported by the comparative studies of antimycotic potential of thyme and clove oil ( $S$. aromaticum) extracts with antifungal activity on C. albicans (Dean and Burchard, 1996; Moore and Atldo, 1977). Though thyme (Thymus vulgaris) oil was more antifungal than the clove ( $S$. aromaticus) oil however, the antifungal activity of clove was moderate at sublethal concentrations used, signifying that only high concentrations of the extract could be appreciable for mycotic infections, especially for oral or vaginal thrush induced by $C$. albicans. The activity profile of $A$. carambola on test organism was similarly significant $(P<$ $0.05)$ : $P$. mirabilis was moderately inhibited with IZD of $14.5 \pm 0.00 \mathrm{~mm}$. This observation is in accordance with the findings of Basu and Hazra (2006) on the inhibition profile of the plant which moderately inhibited the growth of $E$. coli and Shigella dysenteriae with the zone of inhibition of $12 \mathrm{~mm}$ each. A. carambola therefore shows promising use against both gastrointestinal and urinary tract pathogens.

The observed in vitro antihelminthic activity of test plant extracts indicates the potential of the plants to exhibit high morbidity and mortality on the test organisms, particularly at the $20 \mathrm{mg} / \mathrm{ml}$ concentrations used. This activity compares significantly with the standard chemical agent piperazine (of common use among the local populace) at same concentration. The significance of this assay is the evidence (from available results) that the plant extracts used have shown great promises in ethnomedicinal uses as both antimicrobial and antihelminthic compounds and should in addition to their established uses especially as spices, be further standardized and incorporated into capsules, tablets or other formulations for easy acceptability to the local populace.

\section{REFERENCES}

Alves TMD, Silva AF, Brandao M, Grandi TSM, Smania EDA, Junior AS, Zani CL (2000). Biological screening of Brazilian medicinal plants. Mem. Inst. Oswaldo Cruz, 95:367-373.

Ankri S, Mirelman D (999). Antimicrobial properties of allicin from garlic. Microbes Infect. 1:125-129.

Apata L (1992). The Practice of Herbarium in Nigeria. In Africa
Medicinal Plants. Sofowora, Univ. Ife Press, PP. 13-19.

Bakri IM, Douglas CW (2005). Inhibitory effect of garlic extract on oral bacteria. Arch. Oral Biol. 50:645-651

Bagchi GD, Singh A, Khanuja SPS, Bansal RP, Singh SC, Kumar S (1999). Wide spectrum antibacterial and antifungal activities in the seeds of some coprophilous plants of North Indian plains. J. Ethnopharmacol. 64:69-77.

Basu B, Hazra B (2006). Evaluation of nitric acid scavenging activity, in vitro and ex vivo of the selected medicinal plants traditionally used in inflammatory diseases. Phytother. Res. 20:896-900.

Begum S, Wahab A, Siddiqui BS (2003). Pentacyclic triterpenoids from the aerial parts of Lantana camara. Chem. Pharm. Bull. 51:134-137.

Caporaso N, Smith SM, Eng RH (1983). Antifungal activity in human urine and serum after ingestion of garlic (Allium sativum). Antimicrob. Agents Chem. 23:700-702.

Davies J (1994). Inactivation of antibiotics and the dissemination of resistance genes. Science 264:375-382.

Dean DA, Burchard KW (1996). Fungal infection in surgical patients. Am. J. Surg. 171:374-382.

Dibua UE, Okpokwasili GC (2006). Production of some virulence factors under different growth conditions and antibiotic susceptibility patterns of Aeromonas hydrophila. Ann. Res. Int. 3(2):439-447

Dupont S, Caffin N, Bhandari B, Dykes GA (2006). In vitro antibacterial activity of Australian native herb extracts against food related bacteria, Food Control 17:929-932.

Edeoga HO, Okwu DE, Mbaebie BO (2005). Phytochemical constituents of some Nigerian Medicinal plants. Afr. J. Biotechnol. 4:685-688.

Esimone CO, Adikwu M (1999). Antimicrobial properties and cytotoxicity of Ramalina farinacea. Fitoterapia, 70:428-431

Gadkari JV, Joshi VD (1991). Effect of ingestion of raw garlic on serum cholesterol level, clotting time and fibrinolytic activity in normal subjects. J. Postgrad. Med. 37:128-131

Gonzalez CE, Venzon D, Lee S, Mueller BU, Pizzo PA, Walsh TJ (1996). Risk factors for fungemia in children infected with human immunodeficiency virus: a case-control study. Clin. Infect. Dis. 23: 515-521.

Grieve M (1995). Bladderwrack. Botanical.com A Modern Herbal. [http://www.botanical.com].

Harborne JB (1973). Phytochemical methods. In: A guide to Modern Techniques of Analysis. Chapman and Hall Publishers, London, Pp. 4-7.

Ibe AE, Martin IN (2005). Identification, Collection and Domestication of Medicinal Plants in Southeastern Nigeria. Afr. Dev. 30(3):66-77

Idu M, Onyibe L (2007). Antimicrobial activity of some plants in Africa. Res. J. Med. Plants 4(2):32-41.

Jabbar A, Taleb M, Rashid MA, Hasan CN (1995). 5-Hydroxy methylfurfural from Averrhoa carambola Linn. Fitoterapia, 66:377.

Lino A, Deogracious O (2006). The in vitro antibacterial activity of Anona senegalensis, Securidacca lonipendicuata and Stegnotaenia araliacea-Ugandan Medicinal Plants. Afr. Health Sci. 6(1):31-35.

Moore GS, Atldo RD (1977). The fungicidal and fungistatic effects of an aqueous garlic extract on medically important yeast-like fungi. Mycologia 69:341-348.

Morton J (1987). Carambola. In: Fruits of warm climates. Dowling, C.F (Ed). Creative Resources System. Inc. USA, Pp. 125-128.

Muhsin AJ, Amina A (2007). Susceptibility of some Multiple resistant Bacteria to Garlic extract. Afr. J. Biotechnol. 6:771-776.

Nair R, Kalariya T, Chanda S (2005). Antibacterial activity of some selected Indian medicinal flora. Turk. J. Biol. 29:41.

Pérez-Giraldo C, Cruz-Villaon G, Sanchez-Silos R, Martinez-Rubio R, Blanco M, Geomez-Garcia AC (2003). In vitro activity of allicin against Staphylococcus epidermidis and influence of sub-inhibitory concentrations on biofilm formation. J. Appl. Microbiol. 95:709-711.

Sharma OMP, Sharma PD (1989). Natural products of the Lantana plant - the present and prospects. J. Sci. Industr. Res. 48:471-478.

Sieradzki K, Wu SW, Tomasz A (1999). Inactivation of the methicillin resistance gene mecA in vancomycin-resistant Staphylococcus aureus. Micro Drug Resist. 5(4):253-257

Sivam GP, Lampe JW, Ulness B, Swanzy SR, Potter JD (1997). Helicobacter pylori in vitro susceptibility to garlic Allium sativum) 
extract. Nutr. Cancer 27:118-121

Smith A (1998). Development itself is the key to understanding developmental disorders. Trends in Cognitive Sciences, 2(10):389398.

Trease GE, Evans WC (1978). Phytochemistry: Introduction and general methods. Pharmacognosy. $11^{\text {th }}$ Edition, Pp. 227-247

Wink M (1999). Introduction Biochemistry, role and biotechnology of secondary products In: M Wink, Ed, Biochemistry of Secondary Product Metabolism. CRC Press, Boca Raton, FL, Pp. 1-16.

World Health Organization (WHO) (2001). Traditional Medicine Strategy 2002-2005 Geneva: World Health Organization.

Raghu C, Ashoke G, Dhanaraj SA, Suresh B, Vijayan P (2004). In vitro cytotoxic activity of Lantanalcamara (Linn). Indian J. Pharmacol. 36(20):94-95.
Yeh YJ (2001). Supplementation was effective in lowering plasma concentration of total cholesterol. Nutrition 131(3):989S.

Yoshida S, Kasuga S, Hayashi N, Ushiroguchi T, Matsuura H, Nakagawa S (1987). Antifungal activity of ajoene derived from garlic. Appl. Environ. Microbiol. 53:615-617.

Yu S, Qureshi N (1991). National Conference on Cholesterol and high blood pressure. Sponsored by Cholesterol Education Program of the National Institutes of Health. April 8-10,Washington, D.C. 